\title{
The impact of risk and protective factors on online teaching experience in high school Italian teachers during the COVID-19 pandemic
}

\author{
Roberto Truzoli $^{1}$ ( ) | Veronica Pirola ${ }^{1}$ | Stella Conte ${ }^{2}$
}

${ }^{1}$ Department of Biomedical and Clinical Sciences "L. Sacco", University of Milan, Milan, Italy

${ }^{2}$ Department of Education, Psychology, Philosophy, University of Cagliari, Cagliari, Italy

Correspondence

Roberto Truzoli, Department of Biomedical and Clinical Sciences "L. Sacco", University of Milan, via G. B. Grassi 74 20157, Milan, Italy. Email: roberto.truzoli@unimi.it

\begin{abstract}
The lockdown due to COVID-19 in Italy resulted in the sudden closure of schools, with a shift from traditional teaching to the online one. Through an online questionnaire, this survey explores teachers' experience of online teaching, the level of risk factors (e.g., stress) and protective factors (e.g., locus of control) and their impact on satisfaction levels during the social distancing. One hundred seven high school teachers from Lombardy, an Italian region very affected by the COVID-19 outbreak, participated. Results show that depression and stress are the main predictors of satisfaction levels for online teaching. In addition, coping, locus of control and selfefficacy emerge as important protective factors. Finally, although there is great satisfaction with the online teaching experience, critical elements emerged. This study is relevant because it describes the critical elements of the online teaching experience, and identifies some protective factors and the main risk factors in teachers operating in an area strongly marked by social restrictions imposed by the pandemic. High school teachers emerge as a sub-group of the general population with specific psychological reactions. Considering the results, it is possible to suggest providing highquality educational support and crisis-psychological oriented services to teachers, and help to maintain the psychological well-being.
\end{abstract}

\section{KEYWORDS}

COVID-19, online teaching, protective factors, risk factors, social distancing, stress
COVID-19, officially defined as SARS-CoV-2 by the International Committee in Taxonomy of Viruses on 11 February 2020, is a highly infectious epidemic (Li et al., 2020; Wang, Di, et al., 2020). It can be transmitted through respiratory and close contact (Wang, Di, et al., 2020), and in severe cases, it can cause acute respiratory distress syndrome and death (Torales et al., 2020; Wang, Pan, et al., 2020).

Several unprecedented containment measures were taken to limit the spread of the outbreak, focusing on identifying, treating and isolating infected people and promoting precautionary behaviours among the general population, such as social distancing and lockdown in the most affected countries (Qian et al., 2020).
Italy results to be one of the countries strongly affected by COVID-19 (official data: http://opendatadpc.maps.arcgis.com/apps/ opsdashboard/index.html\#/b0c68bce2cce478eaac82fe38d4138b1). On 31 January 2020 in Italy, the Italian Government declared a state of emergency. On 9 March 2020 a new decree-law was signed, introducing new measures for the containment of COVID-19 on the entire national territory, defining all Italy as a "red zone" (Italian Government, Prime Minister's Office, 2020). These measures to contain the contagion have included school closure. The impact of the COVID-19 outbreak has been different in the various Italian regions, with Northern Italy and in particular Lombardy among the worst affected regions. 
In the Italian Sample Survey on Professions (ICP) jointly created by the National Institute for Public Policy Analysis (Inapp) and the National Institute of Statistics (Istat) are reported the number of workers in the educational area and the number of teachers with COVID-19, also distinguished between $<50$ y.o. and $>50$ y.o., and gender. During the first lockdown, in the educational area about 40,000 people were affected (Barbieri et al., 2020; http:// oa.inapp.org/bitstream/handle/123456789/661/Inapp_Barbieri_ Basso_Scicchitano_Italian_Workers_Risk_During_Covid_19_Epidemic 2020.pdf?sequence=2).

So, people have been forced to adopt behaviours of social distancing and isolation (Cantelmi \& Lambiase, 2020), with the request to stay at home and to find alternative ways to manage their daily lives and commitments, as online teaching.

In such an emergency situation, the advantages of containment measures to slow down the spread of COVID-19 must be weighed carefully against the possible psychological consequences, since the uncertainty and fear of the virus not only threaten individuals' physical health but also affect their mental health (Brooks et al., 2020; Li et al., 2020). The potential psychological effects are manifold. First, were reported symptoms of anxiety, depression and other distress reactions as insomnia, somatization, post-traumatic stress disorder and anger (Li et al., 2020; Liu et al., 2020; Lunn et al., 2020; Shigemura et al., 2020; Sood, 2020; Torales et al., 2020; Wang, Di, et al., 2020; Wang, Pan, et al., 2020). Concerning the COVID-19 pandemic, a study in China found rates of $30 \%$ of anxiety and $17 \%$ of depression (Wang, Pan, et al., 2020). In Italy, the prevalence of depression and anxiety symptoms were $24.7 \%$ and $23.2 \%$ (Gualano et al., 2020). Moreover, a report has shown that between $40 \%$ and $50 \%$ of the general population have experienced psychological distress following the COVID-19 outbreak (Moccia et al., 2020), and in general, there has been an increase in rates of subsyndromal mental health problems such as symptoms of depression and anxiety (Rajkumar, 2020; Rossi et al., 2020).

Some studies analysed the impact of bereavement or having had contacts with COVID-19 positive people. Mazza et al. (2020) report that people with a family member infected presented higher levels of anxiety; moreover, having an acquaintance infected was associated with increased levels of both depression and stress.

The teaching profession is recognised as one of the most stressful professions (Johnson et al., 2005). Responses to the COVID-19 pandemic have created new stressors for teachers to deal with. In addition to pre-pandemic stressors such as excessive administrative obligations, strained relationships with colleagues and school leaders and emotional labour (Mercer \& Gregersen, 2020), teachers during the pandemic are also contending with the strains of the pandemic itself, from health concerns, changes due to working from home, managing relationships with students (e.g., the maintenance of a positive student-teacher relationship that is so challenging online).

Job satisfaction is a central construct in understanding the relationship between individuals and their jobs (Judge et al., 2017). Teachers' job satisfaction results from the perceived relationship between what teachers want from their job and what they perceive as offering from the teaching profession ( $\mathrm{Ho} \& \mathrm{Au}, 2006$ ); therefore, this implies a process of evaluation and associated emotions (Locke, 1983). Pre-Covid evidence suggests that online teaching and learning are not necessarily easier or more challenging than conventional teaching and learning (Li \& Akins, 2005; Martínez-Monteagudo et al., 2019; McQuiggan, 2012). However, it is the sudden shift to online teaching that might cause dissatisfaction for some teachers. Recording any levels of dissatisfaction is potentially important because it has been reported that job satisfaction is a critical motivational resource (Zhang et al., 2020).

Herzberg's theory (Herzberg et al., 1959), indicating the mechanisms that link the characteristics of work and job satisfaction, is the most applicable theory for job satisfaction.

In particular, the theory identifies motivating factors that refer not only to job demands, work meaning, and role clarity, but also includes locus of control (Basak \& Ghosh, 2011; Spector, 1997), selfesteem and self-actualization areas.

Generally, the factors which affect teachers' job experience are individual variables (personality, behaviour, attitudes, motivation), and organizational variables (Benţea, 2013; Spector, 1997; Viotti et al., 2020).

Research evidences about the pandemic's impact on schools are still limited and, to our knowledge, there are no Italian publications on peer review journals that particularly analyse risk and protective factors, the role of personality factors on satisfaction with online teaching in Italian high school teachers, and the difficulties related to the educational demands induced by the spread of COVID-19. So, this work will focus on these relevant aspects to improve our knowledge of the critical elements of online teaching during a pandemic. Even at the international level, there is little research on satisfaction with online teaching (cfr. Bao, 2020; Mishra et al., 2020) which, in contrast to our study, used semi-structured interviews or case studies.

In terms of critical environmental situations characterized by uncertainty and unpredictability, while psychopathological variables such as depression, anxiety and stress can make it more difficult to cope with environmental demands, on the other hand, self-efficacy (SE), locus of control (LoC) and coping can play the role of protective factors.

SE is a construct within the social cognitive theory and represents people's beliefs about their capabilities to "organize and execute courses of action required to attain designated types of performances" (Bandura, 1986, p. 391). SE influences also the selection of activities, effort and persistence (Pintrich \& Schunk, 2002), and correlates with self-control (Tangney et al., 2004). Breland et al. (2020) highlight that $\mathrm{SE}$ also plays a role in the actual behaviour to adhere to the precautionary measures for COVID-19.

Teacher's SE reflects previous experiences, beliefs and behaviour and it is a powerful predictor of future behaviour, especially of classroom teaching practices. Teacher SE is one of the teacher characteristics that has been significantly linked not only to teaching behaviour (Riggs et al., 1994), but also to job satisfaction and psychological wellbeing (Ashton, 1984; Caprara et al., 2003; Caprara et al., 2006; Klassen et al., 2009; Zee \& Koomen, 2016). In an international large 
scale survey (Teaching and Learning International Survey; TALIS) involving 73.100 teachers in 23 countries (including Italy), teacher's SE was shown to have an equivalent positive correlation with teaching practices and job satisfaction across countries (Vieluf et al., 2013).

Another construct associated with well-being is LoC, which represents another characteristic of an effective teacher (Lefcourt, 1966; Rotter, 1966). Rotter (1966) distinguished between internal and external LoC. A person's ability and effort are regarded as internal causes of success or failure, whereas chance, fate, powerful others and luck are regarded as external causes.

The interaction between job satisfaction, job motivation and work outcomes has been recognized by most researchers as moderated by LoC (Braun et al., 2013; Hsu, 2011; Ng et al., 2006; Poespowidjojo et al., 2019). As well as with job satisfaction (Bein et al., 1990; Sünbül, 2003), teacher LoC is related to student achievement (Murray \& Staebler, 1974; Weiner, 2003), SE (Parkay et al., 1988), and job attitude (Bedel, 2008; Cheng, 1994; Smith, 1997). The study conducted by Basak and Ghosh (2011) confirmed a significant relationship between job satisfaction with school environment and LoC in school teachers.

Coping consists of mental and behavioural strategies that a person applies to manage critical situations in order to reduce or tolerate stress and conflict (Lazarus, 2006; Lazarus \& Folkman, 1984).

Coping skills are adaptive when they improve the state of psychophysiological well-being. Strategies of coping active and problemfocused were found to be associated with well-being (Drnovšek et al., 2010) and with a better outcome on psychopathological and social variables as a result of psychological therapy (Andres et al., 2003), while active coping, planning and use of emotional social support have been highlighted as predictors of change and responsiveness to Cognitive Behavioural Therapy (CBT) (Premkumar et al., 2011). In general, use of more behavioural, cognitive, or emotional activity that is directed towards a threat ("approach coping", e.g., problem solving or seeking information) and less avoidance coping has been associated with more positive outcomes (Dubow \& Rubinlicht, 2011; Roth \& Cohen, 1986).

The availability of coping resources-that is, practical and psychological tools that help people to meet and overcome environmental demands-can be real characteristics of the environment that allow people to cope with stress (e.g., money availability; Schwarzer \& Leppin, 1991) or internal factors of the individual that help to cope (e.g. SE; Jerusalem \& Schwarzer, 1992). These personal resources are distal predictors of coping strategies. In particular, internal LoC is associated with more problemfocused coping strategies (Parkes, 1994). In teachers, the use of direct coping strategies (mastery orientation and planning) predicts high levels of buoyancy, engagement and well-being, while palliative coping strategies (e.g., failure avoidance) predict low buoyancy, engagement and well-being. (Parker \& Martin, 2009).

In summary, the most effective and adaptive coping strategies are the action and cognitive-focused ones, and the emotional support. In addition, the factors discussed (SE, LoC and coping) emerge as interrelated and can contribute to a greater resilience in front of critical situations.
Finally, we point out that the use of Internet, in addition to being an opportunity (e.g., online interactions will limit the detrimental effects of social isolation), can represent a coping strategy to face difficulties (Romano et al., 2013) which can however have negative consequences, how to promote the development of psychiatric symptoms (Pfefferbaum \& North, 2020) and lead to excessive time spent on social networks (Truzoli et al., 2020; Viganò et al., 2020).

The education system in Italy country is based mostly on classroom education. The situation in general education in the country has changed when the country suddenly had to resort to online teaching because of COVID-19. In 2018 an international survey on teaching and learning TALIS (Teaching and Learning International Survey; http://www.oecd.org/education/talis/talis-2018-country-notes.htm) was conducted with the aim of acquiring information on teachers' teaching practices, also focusing on the use of the information and communication technologies (ICT). The survey showed that in Italy on average only the $35.6 \%$ of Italian teachers felt prepared to use ICT for teaching (Italian Government, Ministry of Education, Ministry of University and Research, 2019). This data, along with the process of an immediate shifting from traditional teaching and learning to the online one may generate several issue and difficulties, also in relation to the levels of perceived satisfaction for online teaching. A study (Fauzi \& Khusuma, 2020) on teachers' elementary school shows that $80 \%$ of teachers feel dissatisfied with online learning. Dissatisfaction was related to various obstacles experienced while doing online learning, including the availability of facilities, network and Internet usage, planning and evaluation of learning, and collaboration with parents. Although some barriers may be associated with a country's level of technological development, others related to the organisation of learning and relational issues are not. In addition to this data, it should be noted that the planned online learning experience is not necessarily equivalent to the experience that is produced from courses presented online as a response to the crisis. Some authors define online teaching during this pandemic as "emergency remote teaching" (Bozkurt \& Sharma, 2020; Hodges et al., 2020). Moreover, while online teaching can refer to several theories and models, the sudden shift from face-to-face to online teaching due to the pandemic did not necessarily go hand-in-hand with a proper planning and design of online instructional programs; often teachers were in the condition of not being able to take advantage of online teaching theories and models.

The crisis-response migration should not be equated to a real digital transformation of schools, but often seems to be an emergency response (Adedoyin \& Soykan, 2020).

During the pandemic, the type and quality of the online teaching experience and satisfaction levels represent a central element of teachers' job satisfaction.

However, as we discussed, teacher's SE is a predictor of classroom teaching practices and it is linked to job satisfaction across countries. LoC represents a characteristic of an effective teacher; in particular, a significant relationship has been highlighted between LoC in school teachers and school environment and job satisfaction and problem-focused coping strategies. In addition, the use of coping 
strategies, as mastery orientation and planning, predicts high levels of well-being in teachers. In literature, SE, LoC and coping emerge as correlated.

Finally, the literature shows a lack of Italian studies both on the experience of online teaching and on the impact of risk and protective factors on online teaching. In particular, as far as we know, the assessments of risk and protective factors during the pandemic, their correlation and their association with perceived satisfaction for online teaching in Italy in high school teachers from an Italian region strongly affected by COVID-19, are not available.

In light of what has been discussed, this study aims to verify the overall impact and influence of some protective and risk factors on satisfaction levels for online teaching of high school teachers, and analyse in detail teachers' evaluation of the online teaching experience.

\section{1 | METHOD}

\section{1 | Participants}

One hundred seven high school teachers from Lombardy took part in the survey (mean age $=49.8, \mathrm{SD}=10.1 ; 38$ males, mean age $=51.3$, $\mathrm{SD}=11.0$; and 69 females, mean age $=49.1, \mathrm{SD}=9.5$ ). In relation to the school in which they teach, participants were distributed as follows: Scientific High School 27 (25.2\%); Classical high School 9 (8.4\%); Linguistic High School 13 (12.1\%); High School of Human Sciences 1 (0.9\%); Technical High School 26 (24.3\%); Trade School 31 (29\%). In addition, the distribution of participants by Province was Milan 56 (52.3\%); Monza and Brianza 16 (15\%); Como 2 (1.9\%); Varese 4 (3.7\%); Bergamo 29 (27.1\%).

\section{2 | Materials}

Online teaching questionnaire (Data S1). Age, gender, school type and province of residence were recorded in the socio-demographic section. The questionnaire consisted of 16 closed-ended questions and 4 open-ended questions (About the question: "In general, regarding online teaching, do you think you know well what to do?" the first open-ended question was: If you answered that you have doubts, indicate your main doubt; About the question: "In general, how satisfied are you with the online teaching activity?" the open-ended questions were: For what main reason did you choose to answer like this?; What did you like most about online teaching?; What did you like least about online teaching?). To check some features of Internet use during the lockdown, we added two other questions related to the Internet use and the time spent on the Internet for purposes other than online teaching. The areas investigated with the 16 questions were: support received from the school, satisfaction of online teaching, teachers' skills, evaluation of students' motivation, communication during distance teaching, impact of online teaching on the person and coping. The last section assessed the degree of exposure to the virus to which teachers were subjected during the COVID-19 pandemic, in terms of direct/indirect exposure, or lack of exposure, or uncertainty about their condition of positivity to the virus. Finally, they were asked if they had suffered the loss of loved ones due to COVID-19 and whether there had been COVID-19 contagions within their own household.

The answers to the questionnaire were expressed on a 4 point Likert scale. In addition, there were questions with multiple-choice answers.

In our sample, the analysis of reliability produced a standardized Cronbach's $\alpha=.79$ (and Guttman L4 = 0.85). The structure validity passed the Kaiser-Meyer-Olkin test $(\mathrm{KMO}=0.80)$ and the Bartlett Test of Sphericity $(p<.0001)$. Content validity has been verified with reference to literature and receiving feedback from expert scholars.

Beck anxiety inventory (Beck et al., 1988) is a 21-items (rating scale 0 -3) self-administered questionnaire assessing the symptoms of anxiety only minimally superimposed on those of a depressive nature. Ratings are for the past week. Items are summed to obtain total scores ranging from 0 to 63 (Beck \& Steer, 1993). Internal consistency is adequate: Cronbach's $\alpha=.92$, and test-retest reliability ( 1 week) $=0.75$ (Beck et al., 1988). The suggested clinical cut-off is $\geq 16$. The questionnaire is a great anxiety screening tool. In the current study, the Italian version developed by Sica and Ghisi (2007) was used.

Locus of control behavior (LCB; Craig et al., 1984) measures the locus of control of behaviour, precisely the generalized expectancies for internal versus external control of the behaviour. The selfadministered questionnaire consists of 17 items (rating scales from 0 to 5); the score can range from 0 to 85 . High scores at the scale indicate the presence of a higher external locus. In this study, the Italian version of the instrument was used, developed by Farma and Cortinovis (2000), whose reliability parameters are like those reported in the original work (Cronbach's $\alpha=.79$ ).

General self-efficacy scale (GSE; Schwarzer \& Jerusalem, 1993, 1995), used to assess an individual's belief in his personal ability to cope with new or difficult situations, is a self-administered scale consisting of 10 items (rating scale 1-4). The score can range from 10 to 40. Cronbach's $\alpha$ values range from .82 to .93 (Schwarzer, 1993; Schwarzer \& Jerusalem, 1993). In this study, the Italian version of the scale was used, developed by Sibilia et al. (1995). GSE is widely used in Italian studies.

Valutazione rapida dello stress (quick stress assessment, VRS; Tarsitani \& Biondi, 1999) is a self-administered scale consisting of 15 items aimed at analysing four psychopathological dimensions (anxiety, depression, somatization and aggression), through clusters of 3 items each, and it also allows to assess the lack of perceived social support (Mandarelli et al., 2004). In this study, total scores (subjective stress) were considered. The score can range from 0 to 45 . The testretest reliability is $r=.84$, and the scale has a good concurrent validity (Tarsitani \& Biondi, 1999).

Center for epidemiologic studies-depression scale (CES-D; Radloff, 1977) is a self-report scale consisting of 20 items (rating scale $0-3)$ that includes six subscales aimed at assessing some dimensions 
of depression: depressed mood, feelings of guilt and worthlessness, feelings of helplessness and despair, psychomotor retardation, loss of appetite and sleep disorders. Cronbach's $\alpha$ coefficients range from .85 to .90 (Radloff, 1977). The suggested clinical cut-off is $\geq 16$. The scale is particularly useful in epidemiological assessments and screening procedures (Balsamo \& Saggino, 2007).

\section{3 | Procedure}

During the months of April and May 2020, in a forced lockdown condition, we conducted the survey using an online questionnaire. At the beginning of the administration, participants were locked down in a state of social distancing for about a month. Teachers were invited to participate through an email sent directly to school directors. School leaders had given a previous willingness to send the invitation to participate to teachers from their own schools.

Before proceeding to answer the questionnaire, all participants received adequate information about the aim of the study and the processing of the data. In addition, all participants provided the informed consent for the processing of sensitive data, the participation in the survey, and the use of the data for research purposes.

\subsection{Statistical analysis}

For the answers to the questionnaire, the percentages per response class were calculated, and the Fisher test was applied to compare the differences between males and females. Spearman's $r$ was calculated for correlations between variables. Point biserial correlation was used for dichotomic variables (gender and COVID-19 exposure). The Mann-Whitney test was applied to verify the differences between the scales used between males and females. Once it was verified that the statistical assumptions were satisfied, ANCOVA was used to identify the explanatory variables of satisfaction levels for online teaching.

\section{5 | Hypothesis}

The aims of this study are: (1) to verify the level of depression, anxiety and stress (risk factors) and protective factors such as LoC, SE and the

TAB BE 1 Mean (SD) of the scales related to LoC, SE, anxiety, stress, and depression, for both the overall sample and for males and females

\begin{tabular}{|llll} 
Test & $\begin{array}{l}\text { Overall sample } \\
\text { Mean (SD) }\end{array}$ & $\begin{array}{l}\text { Males } \\
\text { Mean (SD) }\end{array}$ & $\begin{array}{l}\text { Females } \\
\text { Mean (SD) }\end{array}$ \\
\hline LCB (locus of control) & $25.1(9.1)$ & $26.2(10.1)$ & $24.6(8.5)$ \\
\hline GSE (self-efficacy) & $29.4(3.8)$ & $29.7(3.5)$ & $29.2(4.0)$ \\
\hline BAI (anxiety) & $11.9(10.1)$ & $10.5(7.8)$ & $12.7(11.2)$ \\
\hline VRS (stress) & $14.9(7.2)$ & $14.7(7.8)$ & $15.0(6.9)$ \\
\hline CES-D (depression) & $16.3(9.5)$ & $15.7(9.4)$ & $16.6(9.6)$ \\
\hline
\end{tabular}

type of coping; (2) to identify the correlations between depression, anxiety, stress and protective factors and their correlation with online teaching satisfaction; (3) to identify which variables between risk and protective factors, age, gender and having had COVID-19 cases in the family or having lost a loved one because of COVID-19 explain the satisfaction levels for online teaching; and (4) to highlight positive and negative aspects of the experience of online teaching in high school teachers in the Lombardy region during the social distancing due to COVID-19.

\section{2 | RESULTS}

Results for the scales administered and, subsequently, the results of the questionnaire are presented below.

Table 1 shows the means (SD) of the scales administered for both the overall sample and for males and females.

\subsection{Descriptive data of the scales}

For the overall sample, the scores obtained at the CES-D scale indicate mild depressive symptoms. In particular, 7 males (18.4\%) and 15 females (21.7\%) are in the 16-21 range (mild depression); 7 males (18.4\%) and 18 females (26.1\%) are in the 22-60 range (moderate-tosevere depression). Regarding the different cut-offs, however, no significant differences emerge between males and females $\left(\chi^{2}{ }_{1}=0.08\right.$, $p=.78)$. In general, considering the cut off, 47 participants have a score $>15$ (43.93\%).

Overall, scores at the BAI questionnaire indicate mild anxiety. In particular, 12 males (31.6\%) and 26 females (37.7\%) are in the 8-15 range (mild anxiety); 8 males (21.1\%) and 10 females (14.5\%) are in the 16-25 range (moderate anxiety); and 2 males (5.3\%) and 7 females (10.1\%) have a score $\geq 26$ (severe anxiety). With regard to the different cut-offs, however, no significant differences emerge between males and females $\left(\chi^{2}{ }_{1}=1.54, p=.46\right)$. Overall, considering the cut off, 27 participants have a score $>15$ (25.23\%).

The scores obtained at the LoC scale are 1 standard deviation above the normal values detected by Kumbhar and Gupta (2016). $\mathrm{Md}=25$; overall, 104 participants have a score $\leq 42-$ which corresponds to half of the maximum achievable score, equal to $97.2 \%$. This indicates a prevalence of internal LoC.

Scores at the VRS scale are in line with normative data (Mandarelli et al., 2004; Tarsitani \& Biondi, 1999) and do not indicate acute stress conditions. ( $\mathrm{Md}=13$; overall, 93 participants have a score $\leq 22-$ which corresponds to half of the maximum achievable score, equal to $86.92 \%)$.

The scores obtained at GSE are within the normative values (Scholz et al., 2002). Md = 29; overall, 15 participants have a score $\leq 25$-which corresponds to half of the maximum achievable score, equal to $14.02 \%)$.

At the Mann-Whitney test, for all the scales administered, no significant differences $(p>.4)$ emerge between males and females. 


\subsection{Correlations between risk and protective factors and satisfaction with online teaching}

With regard to the relationship between variables, applying Spearman' $r$, the general satisfaction for online teaching (Question: "In general, how satisfied are you with the online teaching activity?") correlates negatively with the VRS $(r=-.25, p=.009)$, and CES-D $(r=-.23, p=.016)$.

In addition, the BAl scale correlates negatively with GSE $(r=-.35 ; p<.0001)$, and positively correlates with VRS $(r=.65$; $p<.0001)$ and CES-D $(r=.67 ; p<.0001)$.

The VRS scale correlates negatively with GSE ( $r=-.36$; $p<.0001)$, and positively correlates with BAI $(r=.65 ; p<.0001)$ and CES-D ( $r=.78 ; p<.0001)$.

The CES-D scale correlates negatively with GSE $(r=-.39$; $p<.0001)$, and positively with BAI $(r=.67 ; p<.0001)$ and VRS $(r=.78 ; p<.0001)$.

The LCB scale correlates negatively with GSE $(r=-.55$; $p<.0001)$, and positively correlates with VRS $(r=.39 ; p<.0001)$, with BAI $(r=.41 ; p<.0001)$ and CES-D $(r=.41 ; p<.0001)$.

With regard to the LoC scale, it should be noted that high scores at the scale indicate a greater external locus, typical of people who seek confirmation from others more than in themselves and who perceive a favourable situation to them as determined mostly by luck or in any case by events not internal to themselves.

Finally, no significant correlation emerged between stress, gender and COVID-19 exposure (point biserial correlation, $p_{\mathrm{s}}$ always > .53); and no significant correlation emerged between anxiety, depression, stress and have a family member affected $\left(p_{\mathrm{s}}\right.$ always > .37).

In summary, stress and depression correlate negatively with satisfaction with online teaching. Stress also correlates positively with anx iety, depression and LoC, while depression correlates positively with anxiety, stress and LoC. SE correlates negatively with anxiety, stress, depression and LoC.

\subsection{Ancova}

An analysis of covariance was conducted on satisfaction for online teaching. As predictors, all the five scales administered plus age, gender, and having had COVID-19 cases in the family or having lost a loved one because of COVID-19 have been used.

The estimated parameters of the variables that indicate some impact on the model were for depression: value $=-3.42219$; $\mathrm{SE}=1.28215 ; t=-2.66911 ; p=.009 ;$ and for stress: value $=-2.48667 ; \mathrm{SE}=0.97483 ; t=-2.55088 ; p=.012$.

The coefficient of determination for depression was $R^{2}=.063\left(R^{2}\right.$ $\operatorname{adj}=.054)$, and for stress $R^{2}=.058\left(R^{2}\right.$ adj $\left.=.049\right)$.

The analysis of variance revealed a statistically significant effect of depression $F_{(1,105)}=7.124, p=.009$; and stress $F_{(1,105)}=6.507$, $p=.012$. Therefore, we can conclude with confidence that the variables do bring a significant amount of information.
Thus, depression and stress significantly better explain the variability in the dependent variable. Precisely, about $6 \%$ of the variability in the overall satisfaction scores is explained by the explanatory depression variable, and about $5 \%$ by the stress variable.

\subsection{Analysis of the answers to the questionnaire}

Regarding the questionnaire, we report a quantitative summary of the answers for each area investigated (unless otherwise indicated, no significant difference emerged between males and females).

1. Support received from school:

- Do you think you have received clear information from the school on the procedures to be followed for distance learning? $70 \%$ of the overall sample answered A lot or Enough.

\section{Satisfaction with online teaching:}

- As a teaching method, do you prefer online or classroom teaching? Most of the sample (87.9\%) prefers in class.

- What kind of impression did you have on the online teaching experience? A few less than half of the sample (48.6\%) had a positive impression, with a higher percentage of females (53.6\%). Table 2 shows absolute values and percentages of response classes for both the overall sample and for males and females.

Comparing males versus females, significant differences emerge (Fisher test: $p=.01$ ). Females tended to have a more positive impression.

- Do you think that the new student evaluation criteria, formulated for the current circumstance, are adequate? A few less than $40 \%$ of the overall sample considers A little.

- Would you recommend using online education more at school once the COVID-19 emergency is over? About $45 \%$ of the sample answered Yes, but only for additional activities.

- In general, how satisfied are you with the online teaching activity? Over $37 \%$ of the overall sample is a little or no satisfied. More than half $(54.2 \%)$ is quite satisfied. Overall, the responses "satisfied" and "fairly satisfied" account for $62.6 \%$.

- For what main reason did you choose to answer like this? $33.3 \%$ of those who answered a lot answered: having maintained the relationship with the students; and with the same percentage (22.2\%) acquisition of new skills and work organization. $74.3 \%$ of those who answered a little and $60 \%$ of those who answered not at all answered: lack of face-to-face interaction with students.

- What did you like most about online teaching? $41.1 \%$ of the sample answered: acquisition of new skills, and $23.4 \%$ having maintained the relationship with the students.

- What did you like least about online teaching? More than half of the sample (51.4\%) answered: lack of face-to-face interaction with students. 
TABLE 2 Subjective impression about the online teaching experience for both the overall sample and for males and females

\begin{tabular}{llllll}
\multicolumn{4}{l}{ What kind of impression did you have on the online teaching experience? } \\
\hline & Very positive & Positive & Neither positive nor negative & Negative & $18(16.8 \%)$ \\
Overall sample & $7(6.5 \%)$ & $52(48.6 \%)$ & $28(26.2 \%)$ & $7(18.4 \%)$ & $0(0 \%)$ \\
Males & $5(13.2 \%)$ & $15(39.5 \%)$ & $11(28.9 \%)$ & $11(15.9 \%)$
\end{tabular}

TAB LE 3 Opinion about the "know-how" during online teaching for both the overall sample and for males and females

\begin{tabular}{lllll}
\multicolumn{2}{l}{ In general, regarding online teaching, do you think you know well what to do? } \\
\hline & Yes, absolutely & Yes, but I have doubts & No, I have many doubts & Not at all \\
Overall sample & $28(26.2 \%)$ & $68(63.6 \%)$ & $11(10.3 \%)$ & $0(0 \%)$ \\
Males & $14(36.8 \%)$ & $23(60.5 \%)$ & $1(2.6 \%)$ & $0(0 \%)$ \\
Females & $14(20.3 \%)$ & $45(65.2 \%)$ & $10(14.5 \%)$ & $0(0 \%)$ \\
\hline
\end{tabular}

TABLE 4 Perception of the impact of the shift to online teaching on the morale for both the overall sample and for males and females

\begin{tabular}{|c|c|c|c|c|}
\hline Males & 2 (5.3\%) & 7 (18.4\%) & 24 (63.2\%) & 5 (13.2\%) \\
\hline Females & 8 (11.6\%) & 21 (30.4\%) & 39 (56.5\%) & 1 (1.4\%) \\
\hline
\end{tabular}

\section{Teachers' skills:}

- Do you think you have sufficient technological skills to support online teaching? $43 \%$ of the overall sample answered Enough. Most males (47.4\%) said Yes, while most females (49.3\%) answered Enough.

- In general, regarding online teaching, do you think you know well what to do? Almost $64 \%$ of the overall sample has doubts. Males and females differ, with females that have doubts or many doubts for about $80 \%$. Table 3 shows absolute values and percentages of response classes for both the overall sample and for males and females.

Comparing males versus females, significant differences emerge (Fisher test: $p=$.049). Females report more doubts.

At the open-ended question, the main doubt concerns the evaluation criteria, and then the difficulty in communicative feedback.

- With online mode, do you think you have been able to adequately teach new contents? Almost $80 \%$ answered Yes or Enough.

- What is the main difficulty you are facing with distance learning? Just under half of the overall sample (43.9\%) answered "Student assessment" and, to follow, "Interaction with students" (29\%).

- Which statement would better express your experience with online teaching? About half of the sample (46.7\%), despite difficulties, is gaining skills.
4. Students' motivation:

- Do you think students' motivation is adequate? For about $3 / 4$ of the sample $(72.9 \%)$ is adequate or enough adequate.

5. Communication during distance teaching:

- How do you judge the distance communication with your students? For about $3 / 4$ of the sample (73.8\%) is "Adequate, but it can be improved".

- Do you think you can satisfy students' requests for clarification on online lessons? More than $90 \%$ of the sample answered Yes or Enough.

6. Impact of online teaching on the person:

- Do you think that the transition from traditional teaching to online teaching has affected your morale? In the overall sample, about $60 \%$ of the sample suffered a little, and $26.2 \%$ has struggled to handle the situation, but females seem to have suffered the most (30.4\%). Table 4 shows absolute values and percentages of response classes for both the overall sample and for males and females.

Comparing males versus females, significant differences emerge (Fisher test: $p=.04$ ). Females report to have had more impact on the morale. 
TAB LE 5 Strategies used to cope with stress for both the overall sample and for males and females

\begin{tabular}{lllllll} 
When you feel stressed about online teaching what do you usually do? \\
\hline & $\begin{array}{l}\text { I plan the didactic } \\
\text { activity better }\end{array}$ & $\begin{array}{l}\text { I compare myself with } \\
\text { other colleagues }\end{array}$ & $\begin{array}{l}\text { I confide to my } \\
\text { partner/friends }\end{array}$ & $\begin{array}{l}\text { I find alternatives } \\
\text { to relax }\end{array}$ & $\begin{array}{l}\text { I try not to think } \\
\text { about it }\end{array}$ & $\begin{array}{l}\text { I don't feel } \\
\text { stressed out }\end{array}$ \\
Overall sample & $21(19.6 \%)$ & $45(42.1 \%)$ & $7(6.5 \%)$ & $21(19.6 \%)$ & $1(0.9 \%)$ & $12(11.2 \%)$ \\
Males & $7(18.4 \%)$ & $11(28.9 \%)$ & $2(5.3 \%)$ & $9(23.7 \%)$ & $1(2.6 \%)$ & $8(21.1 \%)$ \\
Females & $14(20.3 \%)$ & $34(49.3 \%)$ & $5(7.2 \%)$ & $12(17.4 \%)$ & $0(0 \%)$ & $4(5.8 \%)$ \\
\hline
\end{tabular}

TAB LE 6 Use of the Internet for purposes other than online teaching for both the overall sample and for males and females

\begin{tabular}{|c|c|c|c|c|c|c|c|c|c|c|}
\hline Males & 18 (47.4\%) & 15 (39.5\%) & $0(0 \%)$ & $0(0 \%)$ & $0(0 \%)$ & $3(7.9 \%)$ & $0(0 \%)$ & $0(0 \%)$ & $2(5.3 \%)$ & 0 (0\%) \\
\hline Females & 23 (33.3\%) & 21 (30.4\%) & 11 (15.9\%) & 0 (0\%) & $0(0 \%)$ & 6 (8.7\%) & 3 (4.3\%) & 0 (0\%) & $1(1.4 \%)$ & $4(5.8 \%)$ \\
\hline
\end{tabular}

TAB LE 7 Absolute values and percentages of the potential exposure to COVID-19 and any consequences of infection

\begin{tabular}{|c|c|c|}
\hline $\begin{array}{l}\text { Have you been } \\
\text { exposed to } \\
\text { COVID-19? }\end{array}$ & Absolute values & Percentages (\%) \\
\hline Direct & 4 & 3.7 \\
\hline Indirect & 12 & 11.2 \\
\hline $\begin{array}{l}\text { I do not think I've been } \\
\text { exposed }\end{array}$ & 72 & 67.3 \\
\hline I do not know & 19 & 17.8 \\
\hline $\begin{array}{l}\text { Did you contract the } \\
\text { virus? }\end{array}$ & Absolute values & Percentages (\%) \\
\hline Yes & 0 & 0 \\
\hline No & 52 & 48.6 \\
\hline I do not know & 55 & 51.4 \\
\hline $\begin{array}{l}\text { Did you lose a love } \\
\text { one due to COVID-19? }\end{array}$ & Absolute values & Percentages (\%) \\
\hline Yes & 16 & 15 \\
\hline No & 91 & 85 \\
\hline $\begin{array}{l}\text { Have there been } \\
\text { COVID-19 infections } \\
\text { among your family } \\
\text { members? }\end{array}$ & Absolute values & Percentages (\%) \\
\hline Yes & 19 & 17.8 \\
\hline No & 88 & 82.2 \\
\hline
\end{tabular}

Note: Direct means that the participant had a direct contact with a person who has been found positive to the virus; Indirect means that the participant had a contact with a person who in turn has had contacts with a person who has been found positive to the virus.

- When you feel stressed about online teaching what do you usually do? Social support, in terms of confrontation with one's colleagues, seems to be preferred by females (49.3\%). Table 5 shows absolute values and percentages of response classes for both the overall sample and for males and females.

Comparing males versus females, a tendency to significant differences emerge (Fisher test: $p=.06$ ).

Questions about Internet use:

- Do you use Internet also for other purposes these days? In general, they search for information (38.3\%) and they update through study and training (33.6\%). Social networking seems to be preferred by females (15.9\%). Table 6 shows absolute values and percentages of response classes for both the overall sample and for males and females.

Comparing males versus females, significant differences emerge (Fisher test: $p=.02$ ).

- How much do you use the Internet for purposes other than online teaching these days? The majority (83.2\%) uses the Internet for other purposes $1-3 \mathrm{~h}$, while $3.7 \%$ of the overall sample for more than $7 \mathrm{~h}$ a day.

Table 7 shows the absolute values and percentages of the potential exposure to COVID-19 and any consequences of infection.

More than half of the sample reported a condition of uncertainty as to whether or not they had contracted the virus; $15 \%$ lost a loved one, and about one in five had relatives infected.

\section{3 | DISCUSSION}

The survey took place during a period of social distancing as a way to contain the spread of COVID-19. 
In relation to our first hypothesis (verify the level of depression, anxiety and stress and protective factors such as LoC, SE and the type of coping), it should be considered that on average the total values of stress, anxiety and depression are mild (although almost one in two of the participants exceeds the cut-off of the depression scale, one in four exceeds the cut-off of the anxiety scale and almost one in six has high levels of stress). No difference emerges between males and females.

Since similar studies on Italian teachers are not known, in reference to epidemiological studies on the general population, our sample shows higher rates of depression compared to Italian (Gualano et al., 2020) and Chinese (Wang, Pan, et al., 2020) studies. On the contrary, the percentages of anxiety are substantially in line with the results of the same studies. Finally, stress percentages are lower than those reported by Moccia et al. (2020).

Regarding the protective factors, there is no difference between males and females even between LoC and SE, whose values on average are within the normative values. Large proportions of teachers report an internal LoC and a good SE. Coping strategy seem adequate: finding support from colleagues, planning (cognitive-focused), or looking for relaxing distractions. Taking into account that in teachers the use of adequate coping strategies predicts the levels of well-being (Parker \& Martin, 2009), these data are consistent with the results of our study indicating good SE levels and an adequate internal LoC. Thus, in our sample, protective factors appear to play an important role in reducing the negative psychological consequences due to the pandemic.

Regarding the second hypothesis (identify the correlations between depression, anxiety and stress and protective factors and the correlation of these risk and protective factors with online teaching satisfaction), the correlations highlighted in this study reflect some known data in other populations, as stress is a cross-cutting factor in conditions of anxiety and low mood; and anxiety and depression coexist very often (Truzoli et al., 2015).

In addition, it turns out that the higher are the values of SE, the lower are those of stress, anxiety, depression and internal LoC. Our results are consistent with evidences according to which teacher's SE is significantly linked to psychological well-being (Zee \& Koomen, 2016).

A tendency to an external LoC is associated with less SE; and indeed, those who think about a situation favourable to them as determined by their abilities (internal control) are generally more confident in their abilities. So, it is reasonable that a tendency to an internal LoC is also associated with increased depression and anxiety.

Our results are also consistent with the studies that show a correlation between teachers' LoC and school environment (Basak \& Ghosh, 2011). This data should be interpreted considering that, during the pandemic, the school environment was virtual and that an internal LoC helped to be more self-confident. So, SE and internal LoC seem to play the function of protective factors in the critical situation due to COVID-19 pandemic.

In addition, it should be noted that the most relevant risk factors related to online teaching satisfaction are stress and depression.

This data is reinforced by the results of ANCOVA. In fact, in relation to the third hypothesis (identify which variables between risk and protective factors, age, gender and having had COVID-19 cases in the family or having lost a loved one because of COVID-19 explain satisfaction levels for online teaching), low mood (depression) and stress partially explain the satisfaction levels for online teaching. Many studies have shown that teaching has ranked among the most stressful occupation (Al-Fudail \& Mellar, 2008; Kyriacou, 2001; Travers \& Cooper, 1998). Our study, although it highlights the stress and depression variables as important predictors of dissatisfaction with online teaching, does not detect a general acute stress or depressive condition. In the overall sample, the protective factors are within the normative range and, together with the coping styles, they might have played a positive role in the general framework of having to deal with a complex, sudden situation and with novel elements of teaching practices. Thus, overall our data are consistent with the observation of Martínez-Monteagudo et al. (2019) according to which online teaching is not necessarily more challenging than conventional teaching.

In addition, for some participants, coping with the new and sudden situation has been complicated by some factors such as the uncertainty, bereavement, or suffering. Anyway, while Mazza et al. (2020) report high levels of anxiety in people with a family member infected, in our sample, there is no difference in anxiety levels between people with or without an infected family member; just as there is no difference in levels of depression and stress.

Finally, relative to the fourth hypothesis (highlight positive and negative aspects of the experience of online teaching in high school teachers), the results of the questionnaire on the satisfaction for online teaching present some positive and encouraging aspects, while others are critical.

The first data to consider is that overall a decent percentage of satisfaction emerge, although it should be noted that more than a third of teachers are a little or not satisfied.

To our knowledge, there are no published Italian studies to rely on for a comparison, and the few international studies have verified different hypotheses with a different methodology (Bao, 2020; Mishra et al., 2020). In any case, compared to the results of Fauzi and Khusuma (2020), the percentage of teachers dissatisfied with online learning found in our study is much lower. This data can be interpreted by referring to the different levels of technological development of the two countries (Italy and Indonesia), so that in North Italy the obstacles due to the functioning and availability of the Internet connection are irrelevant. Instead, a common area of difficulty seems to concern the aspects of the assessment and online relationships.

Significant differences emerge on the general impression of the teaching experience, comparing males vs. females. Females tended to have a more positive impression of the teaching experience compared to males, and this despite they had to deal significantly more than males with some elements of uncertainty (doubts about knowing what to do, such as student assessment and communication aspects, which were assessed as adequate but improvable). In addition, the transition to the new teaching mode had an impact on teachers' mood (about a quarter of participants reports they are struggling to manage the situation). Females report a greater impact on mood. The different coping strategies could reasonably explain this apparent contradiction. In fact, in addition to better planning the didactic activity, females tend to use 
more social comparison strategies and social support than males. These coping strategies may have helped to better cope with difficulties, thanks to the activation of a self-assessment process (Locke, 1983) which has resulted in a better impression of the teaching experience.

Although the online teaching experience allows to acquire new skills (most appreciated element of this teaching mode), teaching in the classroom is still widely preferred. This is consistent with the fact that the lack of direct interaction with students is the least appreciated element about online teaching and that there is an orientation to a future use of online teaching for additional activities. This is supported by the evidence that teachers liked anyway the fact that they did not completely lose their relationship with students, even if in a technology-mediated mode. Moreover, teachers in a large percentage believe that they have been able to teach new content, to respond to the students' requests for clarification, who by the way have been perceived as motivated.

A critical element concerns the assessment criteria of students defined in the current situation that were deemed to be a little or nothing adequate by the majority of the sample. The dissatisfaction with student assessment criteria is also likely to discount the national normative uncertainty that exists during data collection.

During social distancing, teachers also used the Internet for other purposes: in general, they search for information and update themselves through study and training. Social networking seems to be preferred by females, thus differing significantly from males. Finally, it is reported that a large majority uses the Internet for purposes other than online teaching 1-3 $\mathrm{h}$, and a small minority for more than $7 \mathrm{~h}$ a day. This latest data on excessive time spent online is consistent with epidemiological research on Problematic Internet Use in the general population (Weinstein \& Lejoyeux, 2010).

This survey expands the evidence on risk and protective factors for Italian high school teachers and their relationship with satisfaction for online teaching during COVID-19 pandemic in an area strongly affected by the pandemic, and reveals some critical aspects of the online teaching experience. High school teachers emerge as a subgroup of the general population with specific psychological reactions. The results of the questionnaire suggest that, all in all, participants have been able to adequately deal with the challenge of shifting to online teaching during the COVID-19 lockdown. However, some issues emerged (some differences between males and females, areas of dissatisfaction such as lack of direct interaction, assessment criteria, impact on mood and distress) that could be considered by school leaders, policymakers and clinicians to improve the procedures and programming of online teaching, plan future online teaching and set up preventive and supportive interventions for psychological distress.

In particular, since it is known that the perception of satisfaction is a critical psychological resource to deal with critical situations such as during a lockdown (Zhang et al., 2020), the focus on depression and stress, can be important to improve perceived satisfaction; and the focus on coping, SE, and LoC can support and help to maintain the balance and the psychological well-being. It is suggested that the government, schools and psychologists should collaborate as an integrated system to face online teaching to provide (1) adequate and timely legislation, including assessment criteria; (2) high-quality educational support, also to improve communication processes; (3) training in stress management and life skills; (4) and crisis-psychological oriented services on request of teachers.

Finally, it will be important for future research to enrich the knowledge of the role of risk and protective factors in a post- or new lockdown condition; in fact, a new post lockdown survey or, better, longitudinal surveys could help us to understand the manifestation or evolution of adaptive and maladaptive behaviours and levels of satisfaction on online teaching.

The work has limitations. First, the sampling is not random, but participants joined by invitation in a voluntary way. Although this may introduce a bias, this participation modality may be acceptable given the exploratory nature of this survey; moreover, it is quite usual in psychological research; finally, the data reflect a sufficiently diversified outcome with respect to the numerical levels of the variables (scales) investigated.

In addition, this study is limited to high school's teachers and therefore the results cannot be automatically generalized to teachers from schools of different grades.

Finally, a certain percentage of Italian schools, although small, use online teaching as their preferred mode, and we do not know if the results of this survey are fully generalizable.

\section{CONFLICT OF INTEREST}

The authors declare no conflicts of interest.

\section{ETHICS STATEMENT}

Participation was voluntarily, and all the data collected anonymously. All procedures were in accordance with the ethical standards of institutional and/or national research committees for studies involving human participants, and with the 1964 Helsinki declaration and its later amendments or comparable ethical standards.

\section{PEER REVIEW}

The peer review history for this article is available at https://publons. com/publon/10.1111/jcal.12533.

\section{DATA AVAILABILITY STATEMENT}

The data that support the findings of this study are available on request at https://dataverse.unimi.it/dataset.xhtml?persistentld= doi:10.13130/RD_UNIMI/TAVIML.

\section{ORCID}

Roberto Truzoli (iD https://orcid.org/0000-0001-7420-7053

\section{REFERENCES}

Adedoyin, O. B., \& Soykan, E. (2020). Covid-19 pandemic and online learning: The challenges and opportunities. Interactive Learning Environments, 1-13. https://doi.org/10.1080/10494820.2020.1813180

Al-Fudail, M., \& Mellar, H. (2008). Investigating teacher stress when using technology. Computers \& Education, 51(3), 1103-1110. https://doi. org/10.1016/j.compedu.2007.11.004 
Andres, K., Pfammatter, M., Fries, A., \& Brenner, H. D. (2003). The significance of coping as a therapeutic variable for the outcome of psychological therapy in schizophrenia. European Psychiatry, 18(4), 149-154. https://doi.org/10.1016/S0924-9338(03)00042-7

Ashton, P. (1984). Teacher efficacy: A motivational paradigm for effective teacher education. Journal of Teacher Education, 35(5), 28-32. https:// doi.org/10.1177/002248718403500507

Balsamo, M., \& Saggino, A. (2007). Test per l'assessment della depressione nel contesto italiano: Un'analisi critica. Psicoterapia Cognitiva e Comportamentale, 13(2), 167-199.

Bandura, A. (1986). Social foundations of thought and action: A social cognitive theory. Prentice Hall.

Bao, W. (2020). COVID-19 and online teaching in higher education: A case study of Peking University. Human Behavior and Emerging Technologies, 2(2), 113-115. https://doi.org/10.1002/hbe2.191

Barbieri, T., Basso, G., \& Scicchitano, S. (2020). Italian workers at risk during the Covid-19 epidemic. INAPP WP, 46, 1-27.Retrieved from http://oa.inapp.org/bitstream/handle/123456789/661/Inapp_Barbieri_ Basso_Scicchitano_Italian_Workers_Risk_During_Covid_19_Epidemic_ 2020.pdf?sequence $=2$

Basak, R., \& Ghosh, A. (2011). School environment and locus of control in relation to job satisfaction among school teachers-A study from Indian perspective. Procedia-Social and Behavioral Sciences, 29, 1199-1208. https://doi.org/10.1016/j.sbspro.2011.11.354

Beck, A. T., Epstein, N., Brown, G., \& Steer, R. A. (1988). An inventory for measuring clinical anxiety: Psychometric properties. Journal of Consulting and Clinical Psychology, 56(6), 893-897.

Beck, A. T., \& Steer, R. A. (1993). Beck anxiety inventory manual. Psychological Corporation.

Bedel, E. F. (2008). Interactions among attitudes toward teaching and personality constructs in early childhood pre-service teachers. Journal of Theory and Practice in Education, 4(1), 31-48.

Bein, J., Anderson, D. E., \& Maes, W. R. (1990). Teacher locus of control and job satisfaction. Educational Research Quarterly, 14(3), 7-10.

Benţea, C. C. (2013). An explanative model for job satisfaction in romanian teachers. Procedia-Social and Behavioral Sciences, 78, 395-399. https://doi.org/10.1016/j.sbspro.2013.04.318

Bozkurt, A., \& Sharma, R. C. (2020). Emergency remote teaching in a time of global crisis due to CoronaVirus pandemic. Asian Journal of Distance Education, 15(1), 1-6.

Braun, S., Peus, C., Weisweiler, S., \& Frey, D. (2013). Transformational leadership, job satisfaction, and team performance: A multilevel mediation model of trust. Leadership Quarterly, 24(1), 270-283. https://doi. org/10.1016/j.leaqua.2012.11.006

Breland, J. Y., Wong, J. J., \& McAndrew, L. M. (2020). Are common sense model constructs and self-efficacy simultaneously correlated with selfmanagement behaviors and health outcomes: A systematic review. Health Psychology Open, 7(1), 1-13. https://doi.org/10.1177/ 2055102919898846

Brooks, S. K., Webster, R. K., Smith, L. E., Woodland, L., Wessely, S., Greenberg, N., \& Rubin, G. J. (2020). The psychological impact of quarantine and how to reduce it: Rapid review of the evidence. The Lancet, 395 (10227), 912-920. https://doi.org/10.1016/S0140-6736(20)30460-8

Cantelmi, T., \& Lambiase, E. (2020, April 2). COVID-19: impatto sulla salute mentale e supporto psicosociale. Istituto di Terapia Cognitivo-Interpersonale-Roma. Retrieved from http://www.toninocantelmi.it/ userfiles/articolo-scientifici/COVID19\%20e\%20salute\%20mentale\% 20ITCI\%202_4_20.pdf

Caprara, G. V., Barbaranelli, C., Borgogni, L., \& Steca, P. (2003). Efficacy beliefs as determinants of teachers' job satisfaction. Journal of Educational Psychology, 95(4), 821-832. https://doi.org/10.1037/00220663.95.4.821

Caprara, G. V., Barbaranelli, C., Steca, P., \& Malone, P. S. (2006). Teachers' self-efficacy beliefs as determinants of job satisfaction and students' academic achievement: A study at the school level. Journal of School
Psychology, 44(6), 473-490. https://doi.org/10.1016/j.jsp.2006. 09.001

Cheng, Y. C. (1994). Locus of control as an indicator of Hong Kong Teachers' job attitudes and perceptions of organizational characteristics. Journal of Educational Research, 87(3), 180-188. https://doi.org/ 10.1080/00220671.1994.9941240

Craig, A. R., Franklin, J. A., \& Andrews, G. (1984). A scale to measure locus of control of behaviour. British Journal of Medical Psychology, 57(2), 173-180. https://doi.org/10.1111/j.2044-8341.1984.tb01597.x

Drnovšek, M., Örtqvist, D., \& Wincent, J. (2010). The effectiveness of coping strategies used by entrepreneurs and their impact on personal well-being and venture performance. Zbornik radova Ekonomskog fakulteta u Rijeci, časopis za ekonomsku teoriju i praksu-Proceedings of Rijeka Faculty of Economics, Journal of Economics and Business, 28(2), 193-220.

Dubow, E. F., \& Rubinlicht, M. (2011). Coping. In B. B. Brown \& M. J. Prinstein (Eds.), Encyclopedia of adolescence (pp. 109-118). Academic Press.

Farma, T., \& Cortinovis, I. (2000). Un questionario sul "Locus of Control": Suo utilizzo nel contesto italiano. Ricerca in Psicoterapia, 3(2-3), 147-155.

Fauzi, I., \& Khusuma, I. (2020). Teachers' elementary school in online learning of COVID-19 pandemic conditions. Jurnal Iqra': Kajian IImu Pendidikan, 5(1), 58-70. https://doi.org/10.25217/ji.v5i1.914

Gualano, M. R., Lo Moro, G., Voglino, G., Bert, F., \& Siliquini, R. (2020). Effects of Covid-19 lockdown on mental health and sleep disturbances in Italy. International Journal of Environmental Research and Public Health, 17(13), 4779. https://doi.org/10.3390/ijerph17134779

Herzberg, F., Mausner, B., \& Snyderman, B. (1959). The motivation to work. John Wiley and Sons.

Ho, C. L., \& Au, W. T. (2006). Teaching satisfaction scale: Measuring job satisfaction of teachers. Educational and Psychological Measurement, 66 (1), 172-185. https://doi.org/10.1177/0013164405278573

Hodges, C., Moore, S., Lockee, B., Trust, T., \& Bond, A. (2020). The difference between emergency remote teaching and online learning. Educause Review, 27. https://epale.ec.europa.eu/en/resource-centre/ content/difference-between-emergency-remote-teaching-and-onlinelearning.

Hsu, Y. R. (2011). Work-family conflict and job satisfaction in stressful working environments. International Journal of Manpower, 32(2), 233-248. https://doi.org/10.1108/01437721111130224

Italian Government, Ministry of Education, Ministry of University and Research (Governo Italiano, Ministero dell'Istruzione, Ministero dell'Università e della Ricerca). (2019, June 19). Scuola, pubblicati i risultati dell'indagine sull'insegnamento e l'apprendimento OCSE TALIS 2018. Retrieved from https://www.miur.gov.it/web/ guest/-/scuola-pubblicati-i-risultati-dell-indagine-sull-insegnamentoe-I-apprendimento-ocse-talis-2018

Italian Government, Prime Minister's Office (Governo Italiano, Presidenza del Consiglio dei Ministri). (2020, February 24). \#loRestoaCasa, misure per il contenimento e gestione dell'emergenza epidemiologica. Retrieved from http://www.governo.it/it/iorestoacasa-misure-governo\#

Jerusalem, M., \& Schwarzer, R. (1992). Self-efficacy as a resource factor in stress appraisal processes. In Self-efficacy: Thought control of action (pp. 195-213). New York, NY: Hemisphere Publishing Corp.

Johnson, S., Cooper, C., Cartwright, S., Donald, I., Taylor, P., \& Millet, C. (2005). The experience of work-related stress across occupations. Journal of Managerial Psychology, 20(2), 178-187. https://doi.org/10. 1108/02683940510579803

Judge, T. A., Weiss, H. M., Kammeyer-Mueller, J. D., \& Hulin, C. L. (2017). Job attitudes, job satisfaction, and job affect: A century of continuity and of change. Journal of Applied Psychology, 102(3), 356-374. https:// doi.org/10.1037/apl0000181

Klassen, R. M., Bong, M., Usher, E. L., Chong, W. H., Huan, V. S., Wong, I. Y. F., \& Georgiou, T. (2009). Exploring the validity of a 
teachers' self-efficacy scale in five countries. Contemporary Educational Psychology, 34(1), 67-76. https://doi.org/10.1016/j.cedpsych.2008. 08.001

Kumbhar, S. B., \& Gupta, D. (2016). Comparison of locus of control behaviour scores in normal and individuals with stuttering-A new way to approach stuttering disorder for speech-language pathologists. International Journal Of Community Health And Medical Research, 2(2), 43-48. https://doi.org/10.21276/ijchmr.2016.2.2.07

Kyriacou, C. (2001). Teacher stress: Directions for future research. Educational Review, 53(1), 27-35. https://doi.org/10.1080/00131910120033628

Lazarus, R. S. (2006). Stress and emotion: A new syntesis. Springer publishing company.

Lazarus, R. S., \& Folkman, S. (1984). Stress, appraisal, and coping. Springer publishing company.

Lefcourt, H. M. (1966). Internal versus external control of reinforcement: A review. Psychological Bulletin, 65(4), 206-220. https://doi.org/10. 1037/h0023116

Li, Q., \& Akins, M. (2005). Sixteen myths about online teaching and learning in higher education: Don't believe everything you hear. TechTrends, 49(4), 51-60.

Li, S., Wang, Y., Xue, J., Zhao, N., \& Zhu, T. (2020). The impact of covid-19 epidemic declaration on psychological consequences: A study on active weibo users. International Journal of Environmental Research and Public Health, 17(6), 2032. https://doi.org/10.3390/ijerph17062032

Liu, S., Liu, Y., \& Liu, Y. (2020). Somatic symptoms and concern regarding COVID-19 among Chinese college and primary school students: A cross-sectional survey. Psychiatry Research, 289, 113070. https://doi. org/10.1016/j.psychres.2020.113070

Locke, E. A. (1983). The nature and causes of job satisfaction. In M. D. Dunnette (Ed.), Handbook of industrial psychology (pp. 1297-1349). Rand-McNally College Publishing Company.

Lunn, P. D., Belton, C. A., Lavin, C., McGowan, F. P., Timmons, S., \& Robertson, D. A. (2020). Using behavioral science to help fight the coronavirus. Journal of Behavioral Public Administration, 3(1), 1-15. https://doi.org/10.30636/jbpa.31.147

Mandarelli, G., Tarsitani, L., Tarolla, E., Robone, C., Battisti, F., Picardi, A., \& Biondi, M. (2004). Stress soggettivo, stato di salute autovalutato e supporto sociale in una popolazione non clinica. Medicina Psicosomatica, 49(3-4), 93-96.

Martínez-Monteagudo, M. C., Inglés, C. J., Granados, L., Aparisi, D., \& García-Fernández, J. M. (2019). Trait emotional intelligence profiles, burnout, anxiety, depression, and stress in secondary education teachers. Personality and Individual Differences, 142, 53-61. https:// doi.org/10.1016/j.paid.2019.01.036

Mazza, C., Ricci, E., Biondi, S., Colasanti, M., Ferracuti, S., Napoli, C., \& Roma, P. (2020). A nationwide survey of psychological distress among Italian people during the COVID-19 pandemic: Immediate psychological responses and associated Factors. International Journal of Environmental Research and Public Health, 17, 3165. https://doi.org/10.3390/ ijerph17093165

McQuiggan, C. A. (2012). Faculty development for online teaching as a catalyst for change. Journal of Asynchronous Learning Networks, 16(2), 27-61.

Mercer, S., \& Gregersen, T. (2020). Teacher wellbeing. Oxford University Press.

Mishra, L., Gupta, T., \& Shree, A. (2020). Online teaching-learning in higher education during lockdown period of Covid-19 pandemic. International Journal of Educational Research Open, 1, 100012. https://doi.org/10. 1016/j.ijedro.2020.100012

Moccia, L., Janiri, D., Pepe, M., Dattoli, L., Molinaro, M., De Martin, V., \& Di Nicola, M. (2020). Affective temperament, attachment style, and the psychological impact of the COVID-19 outbreak: An early report on the Italian general population. Brain, Behavior, and Immunity, 87, 75-79. https://doi.org/10.1016/j.bbi.2020.04.048

Murray, H. B., \& Staebler, B. K. (1974). Teacher's locus of control and student achievement gains. Journal of School Psychology, 12(4), 305-309. https://doi.org/10.1016/0022-4405(74)90050-8
Ng, T. W., Sorensen, K. L., \& Eby, L. T. (2006). Locus of control at work: A meta-analysis. Journal of Organizational Behavior: The International Journal of Industrial, Occupational and Organizational Psychology and Behavior, 27(8), 1057-1087.

Parkay, F. W., Greenwood, G., Olejnik, S., \& Proller, N. (1988). A study of the relationships among teacher efficacy, locus of control, and stress. Journal of Research \& Development in Education, 21(4), 13-22.

Parker, P. D., \& Martin, A. J. (2009). Coping and buoyancy in the workplace: Understanding their effects on teachers' work-related wellbeing and engagement. Teaching and Teacher Education, 25(1), 68-75. https://doi.org/10.1016/j.tate.2008.06.009

Parkes, K. R. (1994). Personality and coping as moderators of work stress processes: Models, methods and measures. Work and Stress, 8(2), 110-129. https://doi.org/10.1080/02678379408259984

Pfefferbaum, B., \& North, C. S. (2020). Mental Health and the Covid-19 Pandemic. The New England Journal of Medicine, 383, 510-512. https://doi.org/10.1056/NEJMp2008017

Pintrich, P. R., \& Schunk, D. H. (2002). Motivation in education: Theory, research, and applications (2nd ed.). Prentice Hall.

Poespowidjojo, D. L., Noor, J., \& Yaacob, M. R. (2019). Internal locus of control affect job performance of commercial television in Indonesia context mediation of job embeddedness. International Journal of Innovative Technology and Exploring Engineering, 8(7), 368-374.

Premkumar, P., Peters, E. R., Fannon, D., Anilkumar, A. P., Kuipers, E., \& Kumari, V. (2011). Coping styles predict responsiveness to cognitive behaviour therapy in psychosis. Psychiatry Research, 187(3), 354-362. https://doi.org/10.1016/j.psychres.2010.12.029

Qian, M., Wu, Q., Wu, P., Hou, Z., Liang, Y., Cowling, B. J., \& Yu, H. (2020). Psychological responses, behavioral changes and public perceptions during the early phase of the COVID-19 outbreak in China: A population based cross-sectional survey. medRxiv. https://doi.org/10.1101/ 2020.02.18.20024448

Radloff, L. S. (1977). The CES-D scale: A self-report depression scale for research in the general population. Applied Psychological Measurement, 1(3), 385-401. https://doi.org/10.1177/014662167700100306

Rajkumar, R. P. (2020). COVID-19 and mental health: A review of the existing literature. Asian Journal of Psychiatry, 52, 102066. https://doi.org/ 10.1016/j.ajp.2020.102066

Riggs, I., Diaz, E., Riggs, M., Jesunathadas, J., Brasch, K., Torner, J., \& Pelletier, A. (1994). Impacting elementary teachers' beliefs and performance through teacher enhancement for science instruction in diverse settings. Paper Presented at the Annual Meeting of the National Association of Research in Science Teaching, Anaheim, CA.

Romano, M., Osborne, L. A., Truzoli, R., \& Reed, P. (2013). Differential psychological impact of internet exposure on internet addicts. PLoS One, 8(2), e55162. https://doi.org/10.1371/journal.pone. 0055162

Rossi, R., Socci, V., Talevi, D., Mensi, S., Niolu, C., Pacitti, F., Di Lorenzo, G. (2020). COVID-19 pandemic and lockdown measures impact on mental health among the general population in Italy. Frontiers in Psychiatry, 11, 790. doi: https://doi.org/10.3389/fpsyt.2020.00790

Roth, S., \& Cohen, L. J. (1986). Approach, Avoidance, and Coping With Stress. American Psychologist, 41(7), 813-819. https://doi.org/10. 1037/0003-066X.41.7.813

Rotter, J. B. (1966). Generalized Expectancies for Internal versus External Control of Reinforcement. Psychological Monographs, 80, 1-28. https://doi.org/10.1037/h0092976

Scholz, U., Doña, B. G., Sud, S., \& Schwarzer, R. (2002). Is general selfefficacy a universal construct? Psychometric findings from 25 countries. European Journal of Psychological Assessment, 18(3), 242-251. https://doi.org/10.1027//1015-5759.18.3.242

Schwarzer, R. (1993). Measurement of perceived self-efficacy. Psychometric scales for cross-cultural research. Freie Universität.

Schwarzer, R., \& Jerusalem, M. (1993). Measurement of perceived self-efficacy: Psychometric scales for cross-cultural research. Freie Universität. 
Schwarzer, R., \& Jerusalem, M. (1995). Generalized self-efficacy scale. In J. Weinman, S. Wright, \& M. Johnston (Eds.), Measures in health psychology: A user's portfolio. Causal and control beliefs (pp. 35-37). NFERNELSON.

Schwarzer, R., \& Leppin, A. (1991). Social support and health: A theoretical and empirical overview. Journal of Social and Personal Relationships, 8 (1), 99-127. https://doi.org/10.1177/0265407591081005

Shigemura, J., Ursano, R. J., Morganstein, J. C., Kurosawa, M., \& Benedek, D. M. (2020). Public responses to the novel 2019 coronavirus (2019-nCoV) in Japan: Mental health consequences and target populations. Psychiatry and Clinical Neurosciences, 74(4), 281-282. https://doi.org/10.1111/pcn.12988

Sibilia, L., Schwarzer, R., \& Jerusalem, M. (1995). Italian adaptation of the general self-efficacy scale. Retrieved from http://userpage.fu-berlin. de/ health/italian.htm

Sica, C., \& Ghisi, M. (2007). The Italian versions of the beck anxiety inventory and the beck depression inventory-II: Psychometric properties and discriminant power. In M. A. Lange (Ed.), Leading-edge psychological tests and testing research (pp. 27-50). NOVA Science Publishers.

Smith, K. E. (1997). Student teachers' beliefs about developmentally appropriate practice: Pattern, stability, and the influence of locus of control. Early Childhood Research Quarterly, 12(2), 221-243. https:// doi.org/10.1016/S0885-2006(97)90015-6

Sood, S. (2020). Psychological effects of the Coronavirus disease-2019 pandemic. Research \& Humanities in Medical Education, 7, 23-26.

Spector, P. E. (1997). Job satisfaction: Application, assessment, causes, and consequences (Vol. 3). Sage publications.

Sünbül, A. M. (2003). An analysis of relations among locus of control, burnout and job satisfaction in Turkish high school teachers. Australian Journal of Education, 47(1), 58-72. https://doi.org/10.1177/ 000494410304700105

Tangney, J. P., Baumeister, R. F., \& Boone, A. L. (2004). High self-control predicts good adjustment, less pathology, better grades, and interpersonal success. Journal of Personality, 72(2), 271-324. https://doi.org/ 10.1111/j.0022-3506.2004.00263.x

Tarsitani, L., \& Biondi, M. (1999). Svilippo e validazione della scala VRS Valutazione rapida dello stress. Medicina Psicosomatica, 44, 163-177.

Torales, J., O'Higgins, M., Castaldelli-Maia, J. M., \& Ventriglio, A. (2020). The outbreak of COVID-19 coronavirus and its impact on global mental health. International Journal of Social Psychiatry, 66(4), 317-320. https://doi.org/10.1177/0020764020915212

Travers, C., \& Cooper, L. (1998). Increasing costs of occupational stress for teachers. In J. Dunham \& V. Varma (Eds.), Stress in teachers: Past, present, and future (pp. 57-75). Whurr.

Truzoli, R., Rovetta, C., Romanó, M., Viganó, C., \& Ba, G. (2015). Effectiveness of a cognitive-behavioral group intervention for comorbid anxiety and mood disorders in partially responder outpatients. Activitas Nervosa Superior Rediviva, 57(4), 89-97.

Truzoli, R., Viganò, C., Galmozzi, P. G., \& Reed, P. (2020). Problematic internet use and study motivation in higher education. Journal of Computer Assisted Learning, 36, 480-486. https://doi.org/10.1111/jcal.12414
Vieluf, S., Kunter, M., \& van de Vijver, F. J. R. (2013). Teacher self-efficacy in cross-national perspective. Teaching and Teacher Education, 35, 92-103. https://doi.org/10.1016/j.tate.2013.05.006

Viganò, C., Molteni, L., Varinelli, A., Virzì, C., Russo, S., Dell'Osso, B., \& Truzoli, R. (2020). Risk of internet addiction in adolescents: A confrontation between traditional teaching and online teaching. The Open Psychology Journal, 13, 79-85. https://doi.org/10.2174/1874350102013010079

Viotti, S., Sottimano, I., Converso, D., \& Guidetti, G. (2020). The relationship between psychosocial characteristics of the work environment and job satisfaction in an Italian public ECE service: A cross-lagged study. Early Childhood Research Quarterly, 53, 464-475. https://doi. org/10.1016/j.ecresq.2020.06.002

Wang, C., Pan, R., Wan, X., Tan, Y., Xu, L., Ho, C. S., \& Ho, R. C. (2020). Immediate psychological responses and associated factors during the initial stage of the 2019 coronavirus disease (COVID-19) epidemic among the general population in China. International Journal of Environmental Research and Public Health, 17(5), 1729. https://doi.org/10. 3390/ijerph17051729

Wang, Y., Di, Y., Ye, J., \& Wei, W. (2020). Study on the public psychological states and its related factors during the outbreak of coronavirus disease 2019 (COVID-19) in some regions of China. Psychology, Health and Medicine, 26, 1-10. https://doi.org/10.1080/13548506.2020.1746817

Weiner, H. (2003). Effective inclusion: Professional development in the context of the classroom. Teaching Exceptional Children, 35(6), 12-18. https://doi.org/10.1177/004005990303500602

Weinstein, A., \& Lejoyeux, M. (2010). Internet addiction or excessive internet use. The American Journal of Drug and Alcohol Abuse, 36(5), 277-283. https://doi.org/10.3109/00952990.2010.491880

Zee, M., \& Koomen, H. M. Y. (2016). Teacher self-efficacy and its effects on classroom processes, student academic adjustment, and teacher wellbeing: A synthesis of 40 years of research. Review of Educational Research, 86(4), 981-1015. https://doi.org/10.3102/0034654315626801

Zhang, S. X., Huang, H., \& Wei, F. (2020). Geographical distance to the epicenter of Covid-19 predicts the burnout of the working population: Ripple effect or typhoon eye effect? Psychiatry Research, 288, 112998. https://doi.org/10.1016/j.psychres.2020.112998

\section{SUPPORTING INFORMATION}

Additional supporting information may be found online in the Supporting Information section at the end of this article.

How to cite this article: Truzoli R, Pirola V, Conte S. The impact of risk and protective factors on online teaching experience in high school Italian teachers during the COVID-19 pandemic. J Comput Assist Learn. 2021;1-13. https://doi.org/10.1111/jcal.12533 